\title{
Superior mesenteric artery syndrome in a healthy adolescent
}

\author{
Kentaro Kogawa, ${ }^{1,2}$ Yoshiki Kusama²
}

'Department of Pediatrics, The Jikei University School of Medicine, Minato-ku, Tokyo, Japan

${ }^{2}$ Department of Pediatrics, Fuji City General Hospital, Fuji,

Shizuoka, Japan

\section{Correspondence to}

Dr Yoshiki Kusama,

stone.bagle@gmail.com

Accepted 1 June 2017
CrossMark

\section{To cite: Kogawa $\mathrm{K}$,} Kusama Y. BMJ Case Rep Published Online First: [please include Day Month Year]. doi:10.1136/bcr-2017220609

\section{DESCRIPTION}

A 12-year-old, previously healthy, girl presented to our hospital with a 3-day history of epigastric pain and vomiting. She also reported having frequent epigastric pain for the past 2 years. Physical examination revealed a body mass index of $13.5 \mathrm{~kg} / \mathrm{m}^{2}$ and abdominal distension. Abdominal contrast-enhanced CT revealed a bloated stomach and a sandwiched horizontal portion of the duodenum between the aorta and superior mesenteric artery (SMA). The angle between the aorta and SMA was $17^{\circ}$, and the aorta-SMA distance was $5.2 \mathrm{~mm}$ (figure $1 \mathrm{~A}, \mathrm{~B}$ ), which met the diagnostic imaging adult criteria for SMA syndrome (SMAS). ${ }^{1}$ An upper gastrointestinal series also revealed that the contrast agent smoothly reached the proximal duodenum, but stopped at the horizontal portion of the duodenum where stenosis was suspected based on CT (figure 1C). Decompression using a nasogastric tube improved her clinical symptoms, and she was discharged. SMAS is characterised by obstruction of the horizontal portion of the duodenum from the compression of the SMA and aorta. Most adult patients have predisposing factors for SMAS, including wasting disease, severe injuries, dietary disorders and postoperative states. ${ }^{2}$ In contrast, SMAS may occur in healthy children and is accompanied by growth spurts during puberty. ${ }^{3}$ The patient's weight increase, which could not catch up to the height increase, was thought to be the cause in this case (figure 2). Therefore, SMAS should be included as a differential diagnosis in adolescent patients with chronic abdominal pain.

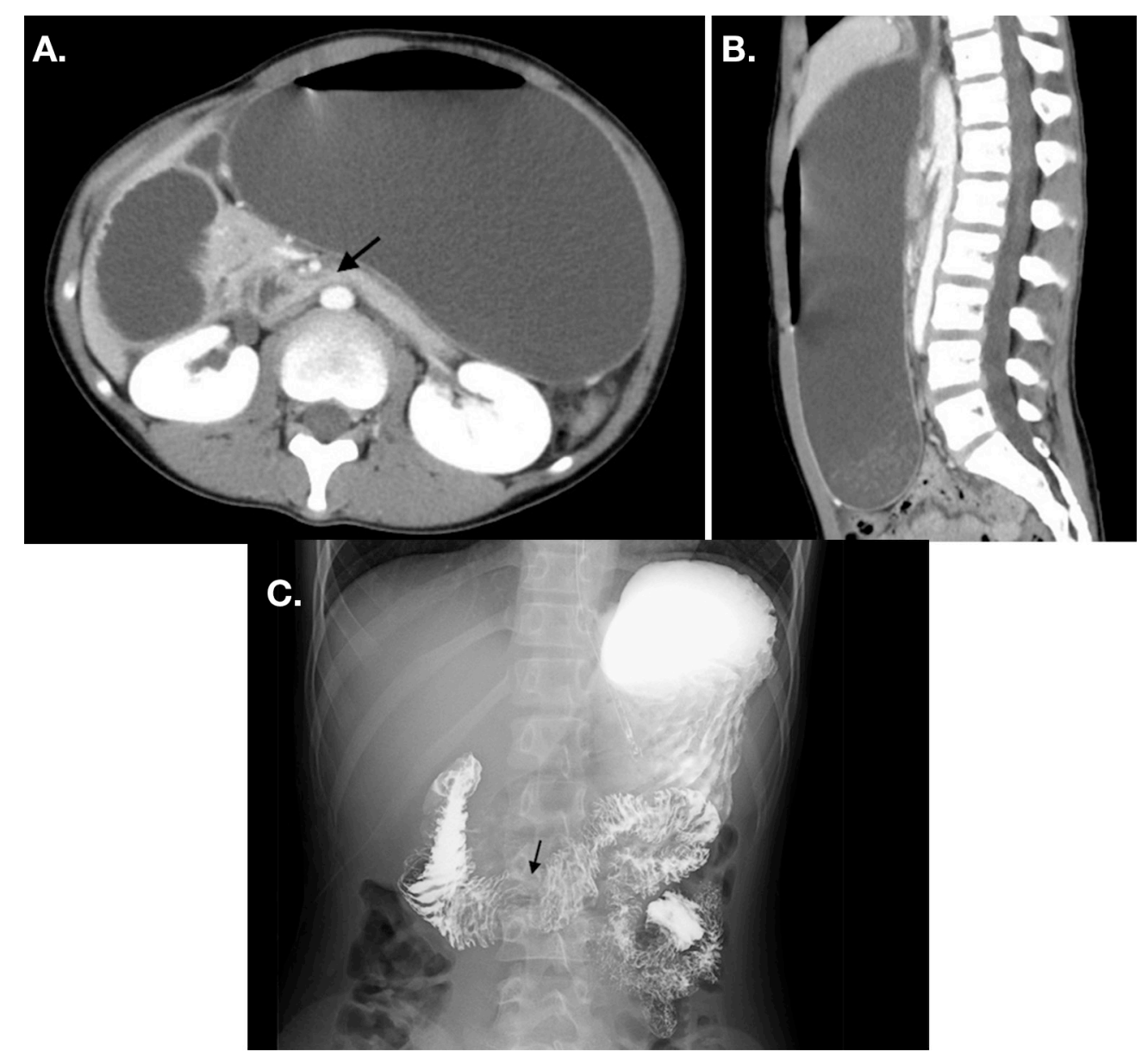

Figure 1 (A) CT axial section shows a sandwiched horizontal portion of the duodenum between the superior mesenteric artery (SMA) and abdominal aorta (arrow), which was was proximal to the duodenal and gastric dilation. The distance between the aorta and SMA is $5.2 \mathrm{~mm}$. (B) CT sagittal section shows a $17^{\circ}$ angle between the aorta and the SMA. (C) An upper gastrointestinal series shows an abrupt cut-off (arrow) at the horizontal portion of the duodenum. 


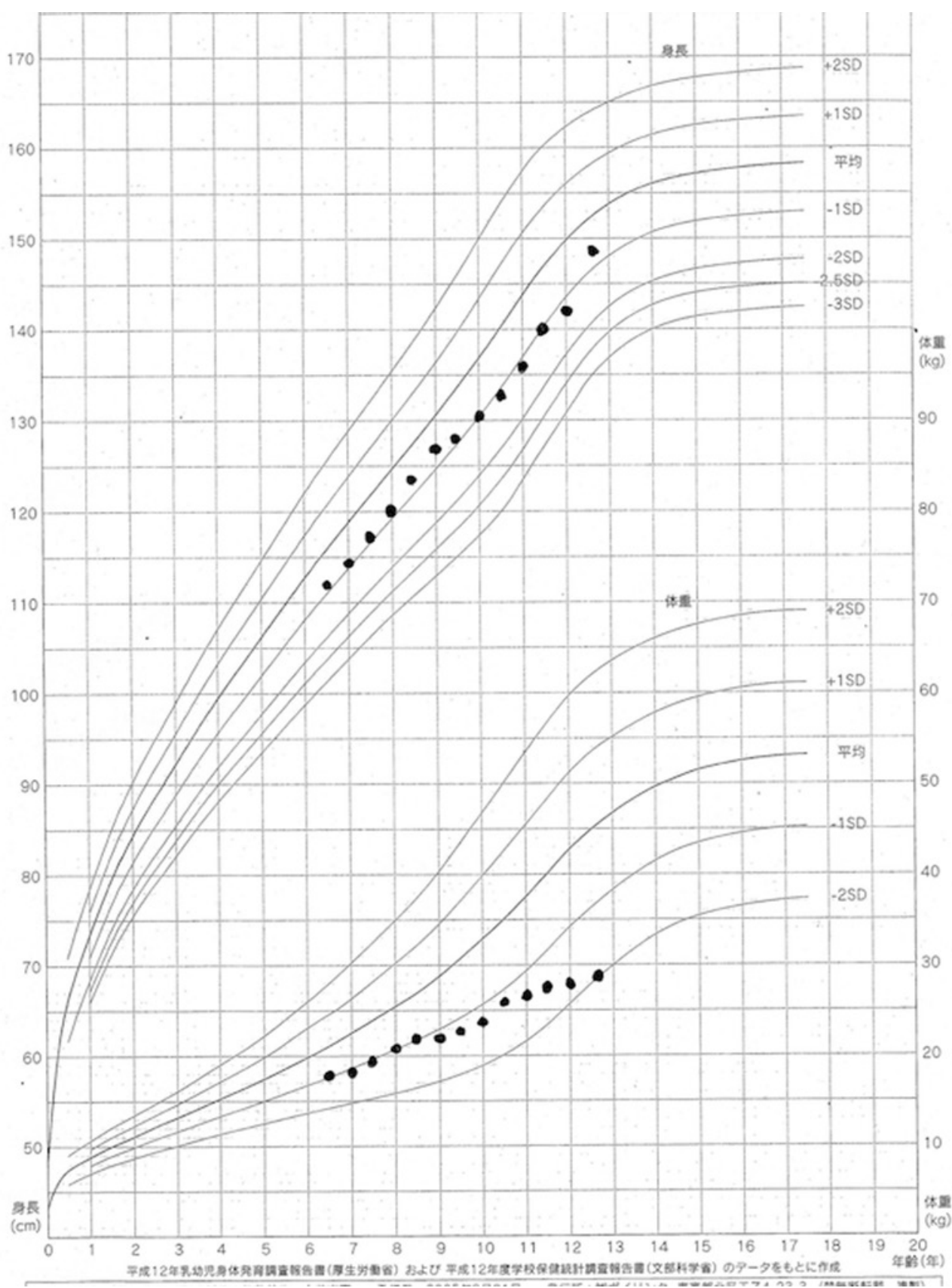

Figure 2 This growth chart demonstrates that the growth in weight was poor, compared with the growth in height.

\section{Learning points}

- Superior mesenteric artery syndrome may occur in healthy children and is accompanied by growth spurts during puberty.

- Superior mesenteric artery syndrome should be included as a differential diagnosis in adolescent patients with chronic abdominal pain.

Contributors KK diagnosed the patient and wrote this article. YK provided specific advice.

Competing interests None declared.
Patient consent Consent obtained from guardian.

Provenance and peer review Not commissioned; externally peer reviewed.

(C) BMJ Publishing Group Ltd (unless otherwise stated in the text of the article) 2017. All rights reserved. No commercial use is permitted unless otherwise expressly granted.

\section{REFERENCES}

1 Unal B, Aktaș A, Kemal G, et al. Superior mesenteric artery syndrome: CT and ultrasonography findings. Diagn Interv Radiol 2005;11:90-5.

2 Panda N, Das R, Gumta M, et al. Wilkie's syndrome: review of eight cases. Acta Gastroenterol Latinoam 2013:43:240-7.

3 Shin MS, Kim JY. Optimal duration of medical treatment in superior mesenteric artery syndrome in children. J Korean Med Sci 2013;28:1220-5. 
Copyright 2017 BMJ Publishing Group. All rights reserved. For permission to reuse any of this content visit http://group.bmj.com/group/rights-licensing/permissions.

BMJ Case Report Fellows may re-use this article for personal use and teaching without any further permission.

Become a Fellow of BMJ Case Reports today and you can:

- Submit as many cases as you like

- Enjoy fast sympathetic peer review and rapid publication of accepted articles

Access all the published articles

Re-use any of the published material for personal use and teaching without further permission

For information on Institutional Fellowships contact consortiasales@bmjgroup.com

Visit casereports.bmj.com for more articles like this and to become a Fellow 